\title{
A Monetary Minsky Model of the Great Moderation and the Great Recession
}

\author{
Abstract \\ Steve Keen’s model of Minsky’s Financial Instability Hypothesis (Steve Keen, 1995) displayed \\ qualitative characteristics that matched the real macroeconomic and income-distributional \\ outcomes of the preceding and subsequent fifteen years: a period of economic volatility followed \\ by a period of moderation, leading to a rise of instability once more and a serious economic \\ crisis. This paper extends that model to build a strictly monetary macroeconomic model which \\ can generate the monetary as well as the real phenomena manifested by both "The Great \\ Recession” and “The Great Moderation”.

\section{Introduction} \\ The financial and economic crisis that began in 2007 brought to an abrupt end a period of \\ economic tranquility that many macroeconomists had celebrated as "The Great Moderation" \\ (Luca Benati and Paolo Surico, 2009, Ben S. Bernanke, 2004, Steven J Davis and James A Kahn, \\ 2008, Jordi Gali and Luca Gambetti, 2009). The trend for recessions to become less frequent and \\ milder abruptly gave way to a sharp decline in output, a doubling of unemployment, and a \\ temporary fall into deflation.
}


Figure 1:The Great Moderation gives way to the Great Recession

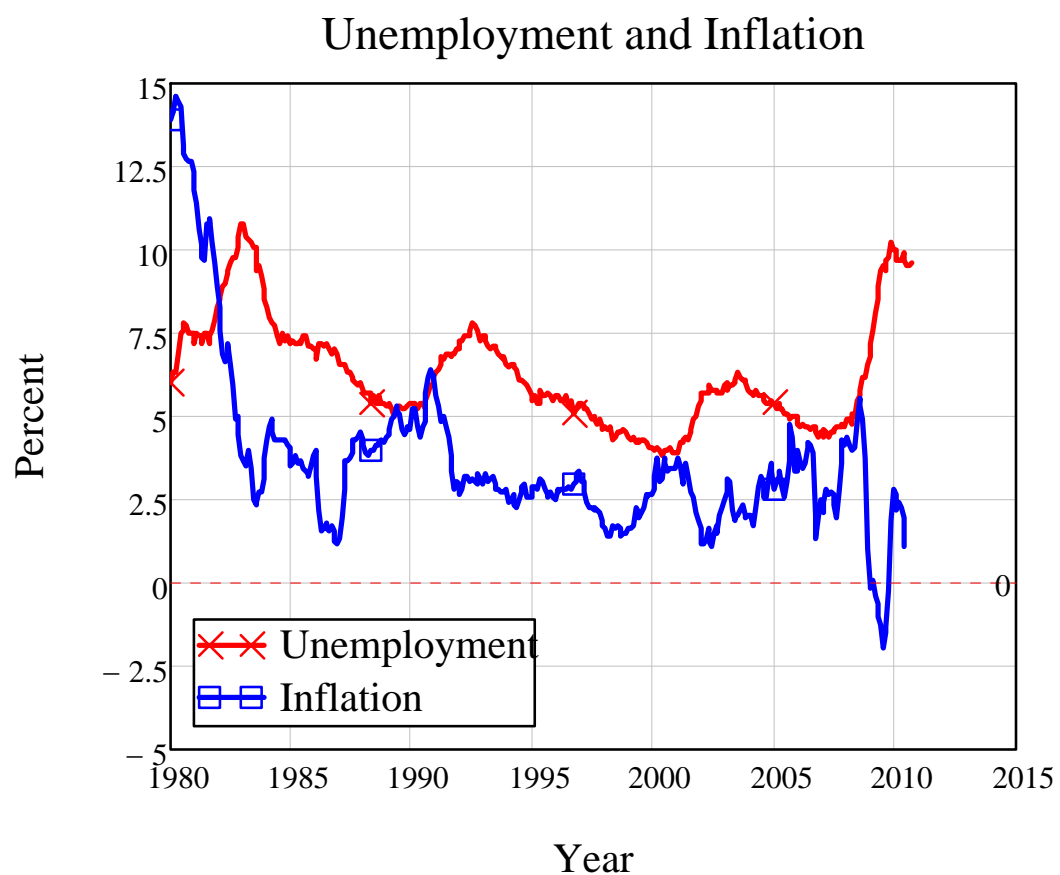

The causes of this economic calamity will be debated for decades, but there should be little debate with the proposition that it was not predicted by any variant of mainstream economic analysis available at the time. It was however a prediction of the non-mainstream "Financial Instability Hypothesis" (FIH) developed by Hyman Minsky.

Steve Keen’s 1995 model of this hypothesis generated qualitative characteristics that matched the real macroeconomic and income-distributional outcomes of the preceding and subsequent fifteen years: a period of economic volatility followed by a period of moderation, leading to a rise of instability once more and a serious economic crisis; and the wage share of income declining while non-financial business incomes stabilised and financial sector earnings rose (Steve Keen, 1995; 2000, p. 93). This model is acknowledged as the reason why Keen was one of the handful of economists to anticipate and warn of the approaching economic and financial crisis well before it actually occurred (Steve Keen 2007; Dirk J Bezemer, 2009, 2010; Edward Fullbrook, 2010).

This paper extends that model to build a strictly monetary macroeconomic model of the FIH, which can generate the monetary as well as the real qualitative characteristics of both "The Great Recession” and “The Great Moderation” that preceded it. I begin with an overview of Minsky’s 
Financial Instability Hypothesis, since many economists are unfamiliar with this nonneoclassical integrated theory of macroeconomics and finance. ${ }^{1}$

The language and concepts in Minsky's theory were also developed completely outside the mainstream economic debate of the past 30 years, ${ }^{2}$ and will therefore appear very foreign to most macroeconomists today. I hope that readers can look past this unfamiliarity to apply the spirit of Friedman's methodological dictum, that what matters is not the assumptions of a theory, but its capacity to give accurate predictions (Milton Friedman, 1953).

\section{The Financial Instability Hypothesis-Genesis}

Minsky’s motivation for developing the Financial Instability Hypothesis was that, since the Great Depression had occurred, a valid economic theory had to be able to generate such an outcome as one of its possible states:

Can “It”- a Great Depression-happen again? And if “It” can happen, why didn’t “It” occur in the years since World War II? These are questions that naturally follow from both the historical record and the comparative success of the past thirty-five years. To answer these questions it is necessary to have an economic theory which makes great depressions one of the possible states in which our type of capitalist economy can find itself. (Hyman P. Minsky, 1982a, p. 5)

\footnotetext{
${ }^{1}$ In addition to being based on unfamiliar theoretical and philosophical foundations, Minsky's work has mainly been published in non-mainstream journals such as the Journal of Post Keynesian Economics and the Journal of Economic Issues, and minor journals such as the Nebraska Journal of Economics and Business. Minsky has appeared only twice in the AER: Hyman Minsky 1957 and 1971.

2 The evolution of Minsky's hypothesis is discussed in detail in Steve Keen, 1995 and 2001. Hyman Minsky, 1982b provides his most important papers (the introduction and Chapters 1-5 are sufficient). I also recommend Minsky 1975. His final book Stabilizing an Unstable Economy Hyman Minsky, 1986, is a far less useful guide to his theories than these earlier works.
} 
For this reason, Minsky explicitly rejected neoclassical economics:

The abstract model of the neoclassical synthesis cannot generate instability. When the neoclassical synthesis is constructed, capital assets, financing arrangements that center around banks and money creation, constraints imposed by liabilities, and the problems associated with knowledge about uncertain futures are all assumed away. For economists and policy-makers to do better we have to abandon the neoclassical synthesis. (Hyman P. Minsky, 1982a, p. 5)

Minsky instead combined insights from Schumpeter, Fisher and Keynes to develop a theory of financially-driven business cycles which can lead to an eventual debt-deflationary crisis.

\section{The Financial Instability Hypothesis-a Précis ${ }^{3}$}

Minsky's analysis of a financial cycle begins at a time when the economy is doing well (the rate of economic growth equals or exceeds that needed to reduce unemployment), but firms are conservative in their portfolio management (debt to equity ratios are low and profit to interest cover is high), and this conservatism is shared by banks, who are only willing to fund cash-flow shortfalls or low-risk investments. The cause of this high and universally practised risk aversion is the memory of a not too distant system-wide financial failure, when many investment projects foundered, many firms could not finance their borrowings, and many banks had to write off bad debts. Because of this recent experience, both sides of the borrowing relationship prefer extremely conservative estimates of prospective cash flows: their risk premiums are very high.

However, the combination of a growing economy and conservatively financed investment means that most projects succeed. Two things gradually become evident to managers and bankers: "Existing debts are easily validated and units that were heavily in debt prospered: it pays to lever.” (Hyman P. Minsky, 1982a, p. 6). As a result, both managers and bankers come to regard the previously accepted risk premium as excessive. Investment projects are evaluated using less

\footnotetext{
33 This summary of Minsky is reproduced from Steve Keen (1995) with the kind permission of the Journal of Post Keynesian Economics.
} 
conservative estimates of prospective cash flows, so that with these rising expectations go rising investment and asset prices. The general decline in risk aversion thus sets off both growth in investment and exponential growth in the price level of assets, which is the foundation both of the boom and its eventual collapse.

More external finance is needed to fund the increased level of investment and the speculative purchase of assets, and these external funds are forthcoming because the banking sector shares the increased optimism of investors (Hyman P. Minsky, 1982b, p. 65). The accepted debt to equity ratio rises, liquidity decreases, and the growth of credit accelerates.

This marks the beginning of what Minsky calls "the euphoric economy" (Hyman P. Minsky, 1982b, p. 121), where both lenders and borrowers believe that the future is assured, and therefore that most investments will succeed. Asset prices are revalued upward as previous valuations are perceived to be based on mistakenly conservative grounds. Highly liquid, low-yielding financial instruments are devalued, leading to a rise in the interest rates offered by them as their purveyors fight to retain market share.

Financial institutions now accept liability structures both for themselves and their customers "that, in a more sober expectational climate, they would have rejected” (Hyman P. Minsky, 1982b, pp. 120-125). The liquidity of firms is simultaneously reduced by the rise in debt to equity ratios, making firms more susceptible to increased interest rates. The general decrease in liquidity and the rise in interest paid on highly liquid instruments triggers a market-based increase in the interest rate, even without any attempt by monetary authorities to control the boom. However the increased cost of credit does little to temper the boom, since anticipated yields from speculative investments normally far exceed prevailing interest rates, leading to a decline in the elasticity of demand for credit with respect to interest rates.

The condition of euphoria also permits the development of an important actor in Minsky's drama, the Ponzi financier (Hyman P. Minsky, 1982b, p. 123; James K. Galbraith, 1955, pp. 45). These capitalists profit by trading assets on a rising market, and incur significant debt in the process. The servicing costs for Ponzi debtors exceed the cash flows of the businesses they own, but the capital appreciation they anticipate far exceeds the interest bill. They therefore play an 
important role in pushing up the market interest rate, and an equally important role in increasing the fragility of the system to a reversal in the growth of asset values.

Rising interest rates and increasing debt to equity ratios eventually affect the viability of many business activities, reducing the interest rate cover, turning projects which were originally conservatively funded into speculative ones, and making ones which were speculative "Ponzi”. Such businesses will find themselves having to sell assets to finance their debt servicing-and this entry of new sellers into the market for assets pricks the exponential growth of asset prices. With the price boom checked, Ponzi financiers now find themselves with assets which can no longer be traded at a profit, and levels of debt which cannot be serviced from the cash flows of the businesses they now control. Banks which financed these assets purchases now find that their leading customers can no longer pay their debts_-and this realisation leads initially to a further bank-driven increase in interest rates. Liquidity is suddenly much more highly prized, holders of illiquid assets attempt to sell them in return for liquidity. The asset market becomes flooded and the euphoria becomes a panic, the boom becomes a slump.

As the boom collapses, the fundamental problem facing the economy is one of excessive divergence between the debts incurred to purchase assets, and the cash flows generated by them-with those cash flows depending both upon the level of investment and the rate of inflation. The level of investment has collapsed in the aftermath of the boom, leaving only two forces which can bring asset prices and cash flows back into harmony: asset price deflation, or current price inflation. This dilemma is the foundation of Minsky's iconoclastic perception of the role of inflation, and his explanation for the stagflation of the 70s and early 80s.

Minsky argues that if the rate of inflation is high at the time of the crisis, then though the collapse of the boom causes investment to slump and economic growth to falter, rising cash flows rapidly enable the repayment of debt incurred during the boom. The economy can thus emerge from the crisis with diminished growth and high inflation, but few bankruptcies and a sustained decrease in liquidity. Thus though this course involves the twin "bads" of inflation and initially low growth, it is a self-correcting mechanism in that a prolonged slump is avoided. However the conditions are soon re-established for the cycle to repeat itself, and the avoidance of a true calamity is likely to lead to a secular decrease in liquidity preference. 
If the rate of inflation is low at the time of the crisis, then cash flows will remain inadequate relative to the debt structures in place. Firms whose interest bills exceed their cash flows will be forced to undertake extreme measures: they will have to sell assets, attempt to increase their cash flows (at the expense of their competitors) by cutting their margins, or go bankrupt. In contrast to the inflationary course, all three classes of action tend to further depress the current price level, thus at least partially exacerbating the original imbalance. The asset price deflation route is, therefore, not self-correcting but rather self-reinforcing, and is Minsky’s explanation of a depression.

The above sketch describes Minsky's perception of an economy in the absence of a government sector. With big government, the picture changes in two ways, because of fiscal deficits and Reserve Bank interventions. With a developed social security system, the collapse in cash flows which occurs when a boom becomes a panic will be at least partly ameliorated by a rise in government spending — the classic “automatic stabilisers”, though this time seen in a more monetary light. The collapse in credit can also be tempered or even reversed by rapid action by the Reserve Bank to increase liquidity.

\section{Modeling Minsky I: the Goodwin model}

Minsky’s own attempts to devise a mathematical model of his hypothesis were unsuccessful, ${ }^{4}$ arguably because the foundation he used — the multiplier-accelerator model—was itself flawed (Steve Keen, 2000, pp. 84-89). Steve Keen (1995) instead used Goodwin’s growth cycle model (Richard Goodwin, 1967), which generates a trade cycle with growth out of a simple deterministic structural model of the economy.

Goodwin's model can be expressed as two differential equations in the rate of employment and the wages share of output. I outline it here in terms of absolute values, since this is the form in which the final monetary Minsky model in this paper is expressed. The basic deterministic causal cycle of the model is:

\footnotetext{
4 The first of Minsky's two papers in the AER set out a mathematical model of a financially driven trade cycle developed during his $\mathrm{PhD}$, but he never attempted to develop the model further (Hyman P. Minsky, 1957).
} 
1. The level of capital stock $K$ determines the level of output per annum $Y$ via the accelerator $v: Y=\frac{K}{v}$

2. The level of output determines the level of employment $L$ via labor productivity $a$ : $L=\frac{Y}{a}$

3. The level of employment determines the employment rate $\lambda$ (the ratio of $L$ to population $N): \lambda=\frac{L}{N}$

4. The employment rate determines the rate of change of real wages $w$ via a Phillips curve:

$$
\frac{1}{w} \frac{d w}{d t}=(-c+d \cdot \lambda)
$$

5. Subtracting the wage rate $w$ times labor $L$ from output $Y$ determines the level of profit $\Pi$; $\Pi=Y-w \cdot L$

6. Profit determines investment $I$ (in the simple Goodwin model, all profits are invested): $I=\Pi$

7. Investment minus depreciation $\gamma$ determines the rate of change of capital stock $K$, closing the model: $\frac{d K}{d t}=I-\gamma \cdot K$

With population growth of $\beta$ percent per annum, labor productivity growth of $\alpha$ percent, and a linear Phillips curve relation of the form $P_{h}(\lambda)=(-c+d \cdot \lambda)$ (where $a$ and $b$ are constants), the model consists of the following 4 differential equations in the level of employment, the real wage, labor productivity and population growth:

$$
\begin{aligned}
& \frac{d}{d t} L=L \cdot\left(\frac{1-\frac{w}{a}}{v}-\gamma-\alpha\right) \\
& \frac{d}{d t} w=(-c+d \cdot \lambda) \cdot w \\
& \frac{d}{d t} a=\alpha \cdot a \\
& \frac{d}{d t} N=\beta \cdot N
\end{aligned}
$$


Cycles in the Goodwin model are caused not by any imposed nonlinearity, but by the structural nonlinearity that the system states of the wage rate and the level of employment are multiplied by each other. Interactions between changes in the distribution of income (which emanate from changes in workers' relative bargaining power as employment levels rise and fall) and the rate of growth then cause cycles: a high level of investment causes high growth, so that unemployment falls - which leads to rising wages and a falling profit share; falling profit share then reduces investment and economic growth, leading to rising unemployment; this reduces wages and restoring profit share, leading the cycle to repeat.

Figure 2: Cyclical growth in the basic Goodwin model

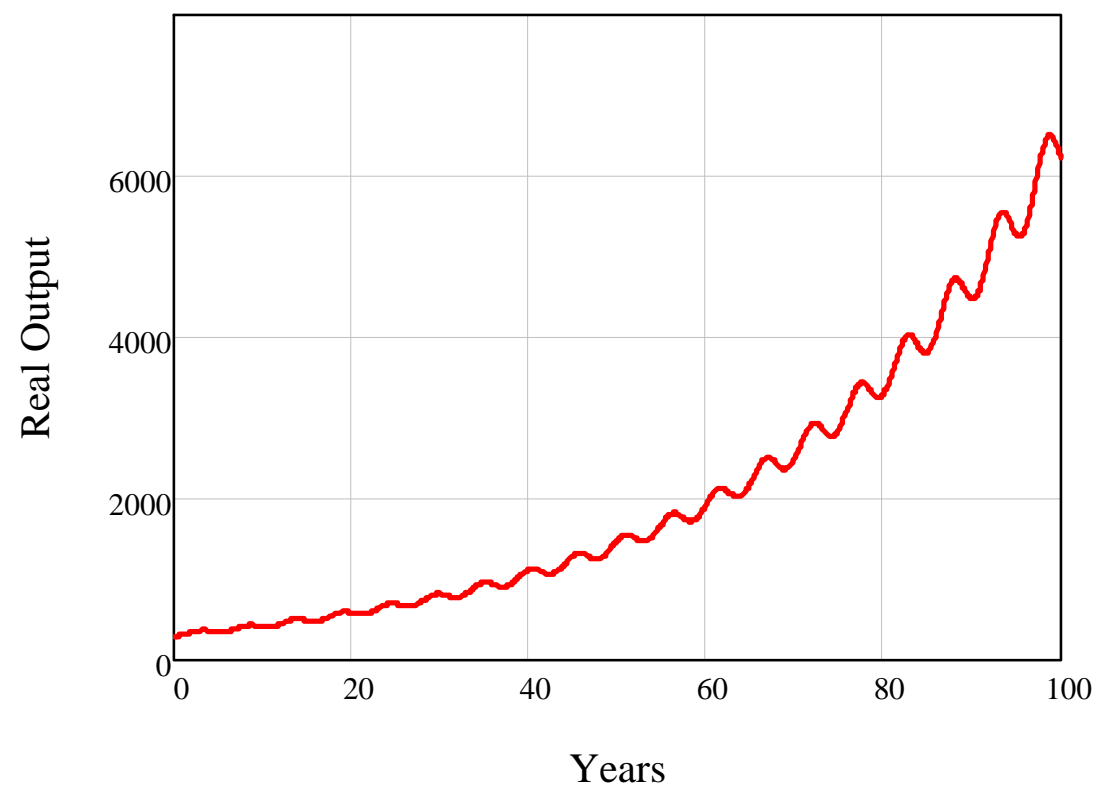




\section{Figure 3: A conservative system}

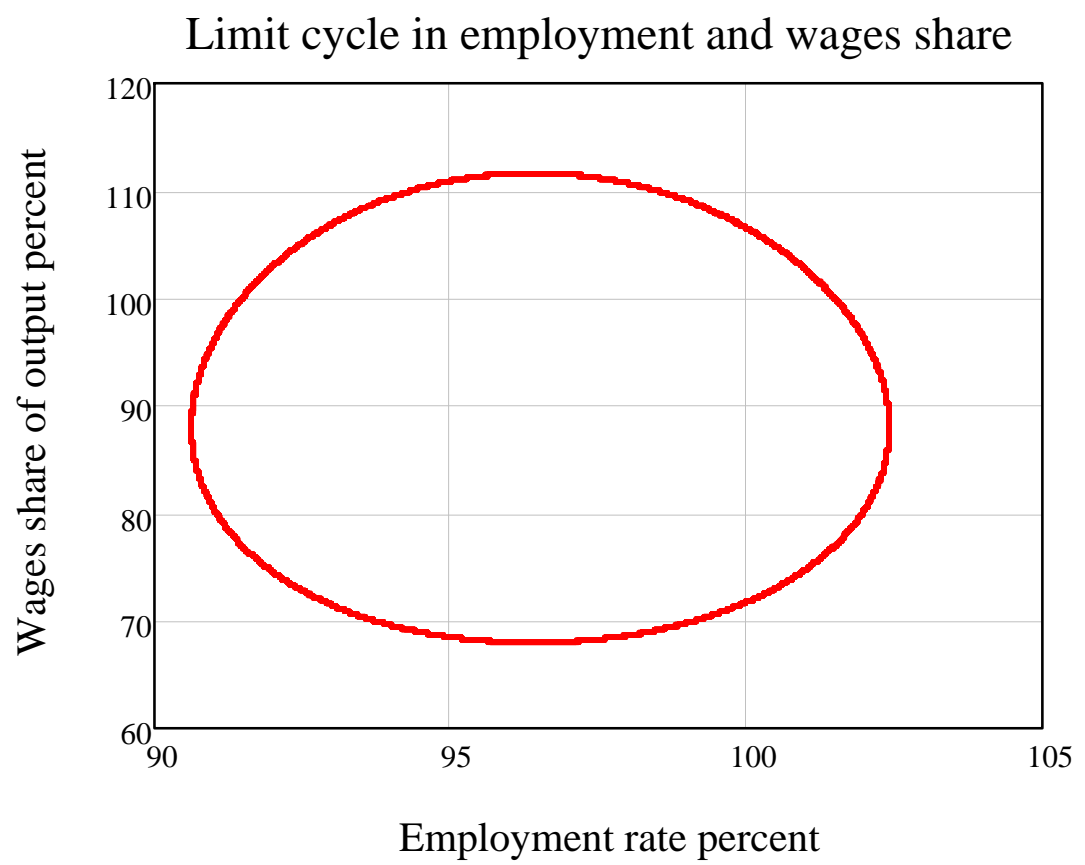

\section{Modeling Minsky II: Nonlinear functions and debt}

An essential first step in modeling Minsky's insights concerning the role of debt finance was to replace the unrealistic linear functions for investment with a more realistic nonlinear relation, so that when the desire to invest exceeds retained earnings, firms will borrow to finance investment. Exponential functions for the propensity to invest captured the most fundamental of Keynes's insights about the behavior of agents under uncertainty: that they behave as if:

the present is a much more serviceable guide to the future than a candid examination of past experience would show it to have been hitherto (J. M. Keynes, 1937, p. 214)

Agents thus extrapolate current conditions into the future, a behavior that Keynes elsewhere describes as "unreasoning and yet in a sense legitimate where no solid basis exists for a reasonable calculation” (J. M. Keynes, 1936, p. 154). Thus desired investment exceeds profits at high rates of profit, and is less than profits at low rates (while with a nonlinear Phillips curve, wages rise rapidly at high levels of employment and fall slowly at lower levels), because agents extrapolate current conditions into the future. 
The same generalized exponential function is used for both the relationship between investment as a share of output and the Phillips Curve:

$$
\operatorname{GenExp}\left(x, x_{v a l}, y_{v a l}, s, \min \right)=\left(y_{v a l}-\min \right) \cdot e^{\frac{s}{\left(y_{v a l}-\min \right)} \cdot\left(x-x_{v a l}\right)}+\min
$$

With suitable parameter values (see the Appendix), the two relationships are

Figure 4: The rate of change of real wages as a function of the employment rate

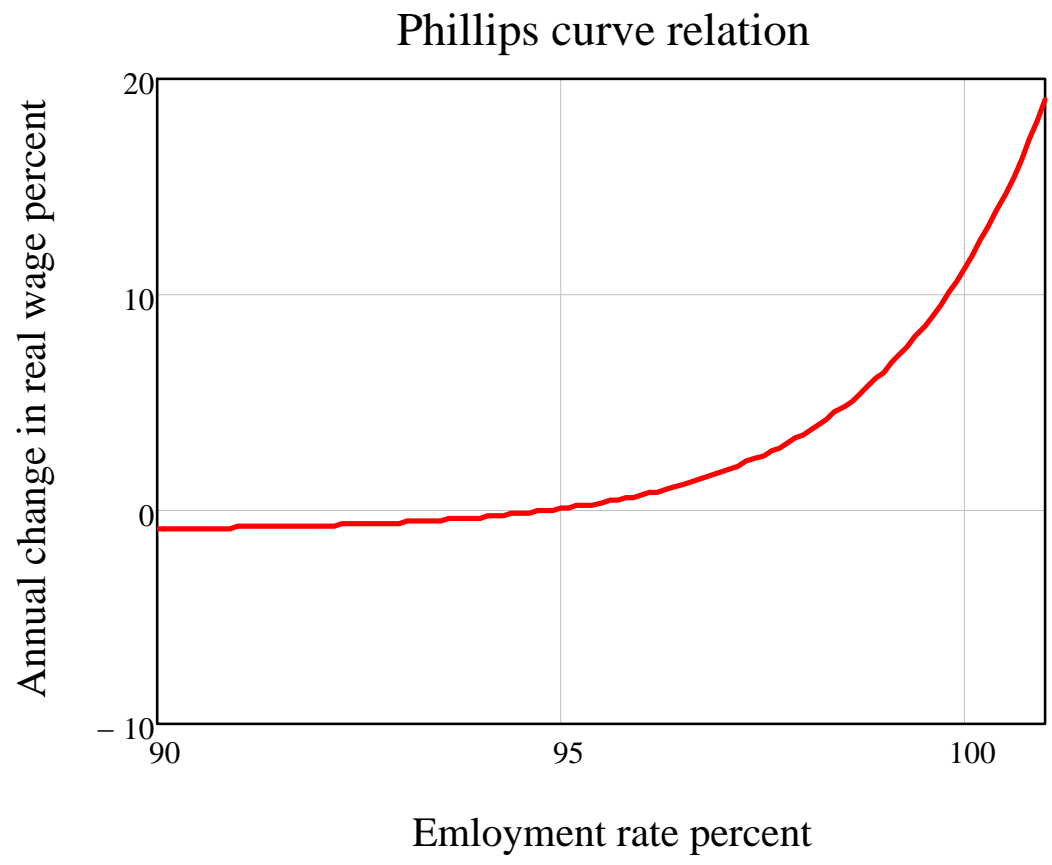


Figure 5: The level of investment in GDP as a function of the rate of profit

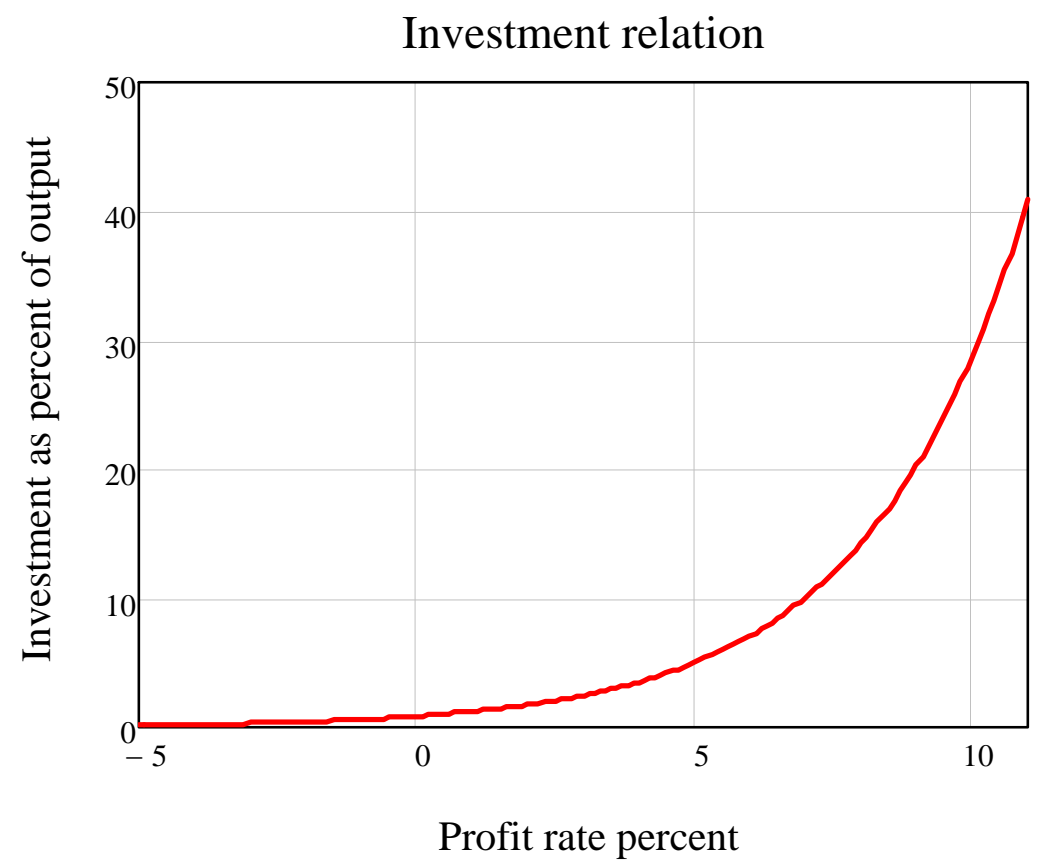

A banking sector that financed the gap between desired and investment was then introduced by the simple relationship that the gap between desired investment and actual profit caused a change in the level of debt:

$$
\frac{d D}{d t}=I-\Pi
$$

Profit is also redefined as output minus the sum of wages plus interest payments:

$$
\Pi=Y-w \cdot L-r \cdot D
$$

This extension adds one more system state to the model, the debt level $D$. Substituting $Y$ for the system state $L$, this results in the model shown in Equation (1.5). 
Monetary Minsky Model of the Great Moderation and Great Recession

$$
\begin{aligned}
& \frac{d}{d t} Y=\left(\frac{I\left(\frac{\Pi}{v \cdot Y}\right)}{v}-\gamma\right) \cdot Y \\
& \frac{d}{d t} w=P_{h}(\lambda) \cdot w \\
& \frac{d}{d t} D=I\left(\frac{\Pi}{v \cdot Y}\right) \cdot Y-\Pi \\
& \frac{d}{d t} a=\alpha \cdot a \\
& \frac{d}{d t} N=\beta \cdot N
\end{aligned}
$$

This additional dimension converts the model from a conservative to a dissipative dynamical system, in which the model's dynamics display sensitive dependence on initial conditions. Specifically, the model has a stable equilibrium — defined in terms of the employment rate, the profit rate and the debt to output ratio - and will converge to this if the initial conditions are sufficiently close to the equilibrium. But for other initial conditions, the model bifurcates (following what is known as the inverse tangent route to chaos; see Yves Pomeau and Paul Manneville, 1980), and the model undergoes an unstable cyclical breakdown.

Figure 6: Cyclical breakdown of growth in the basic Minsky model

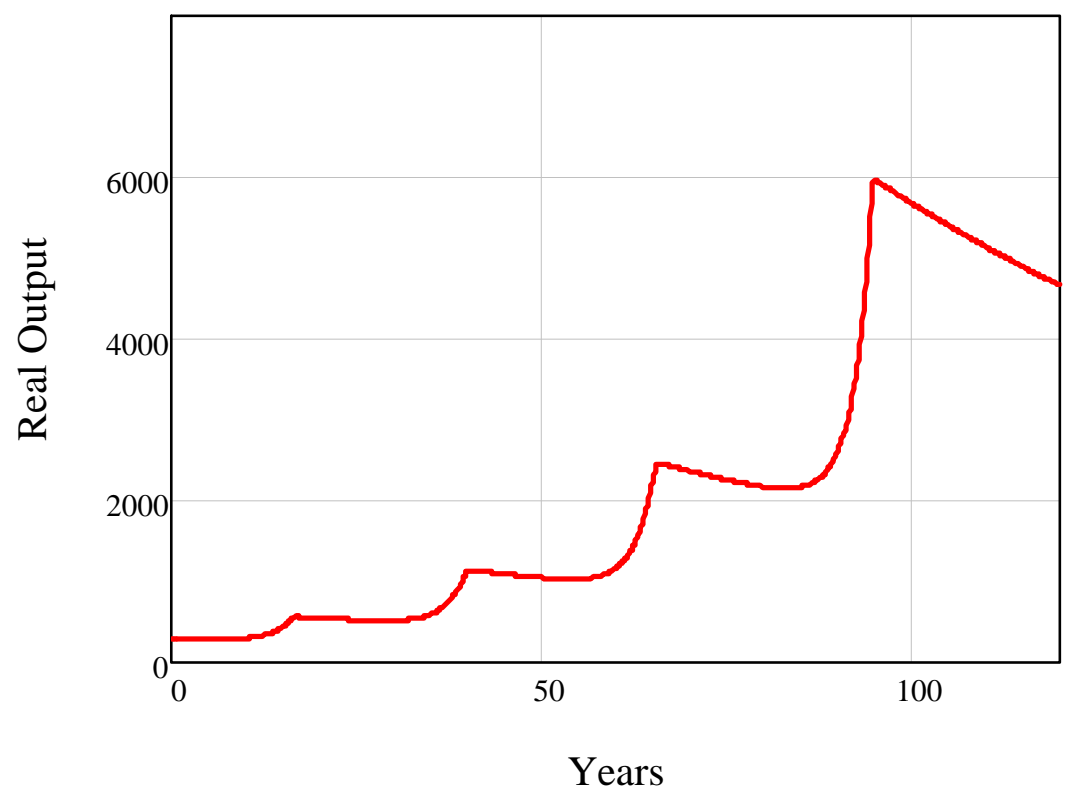


Figure 7: A dissipative system with breakdown

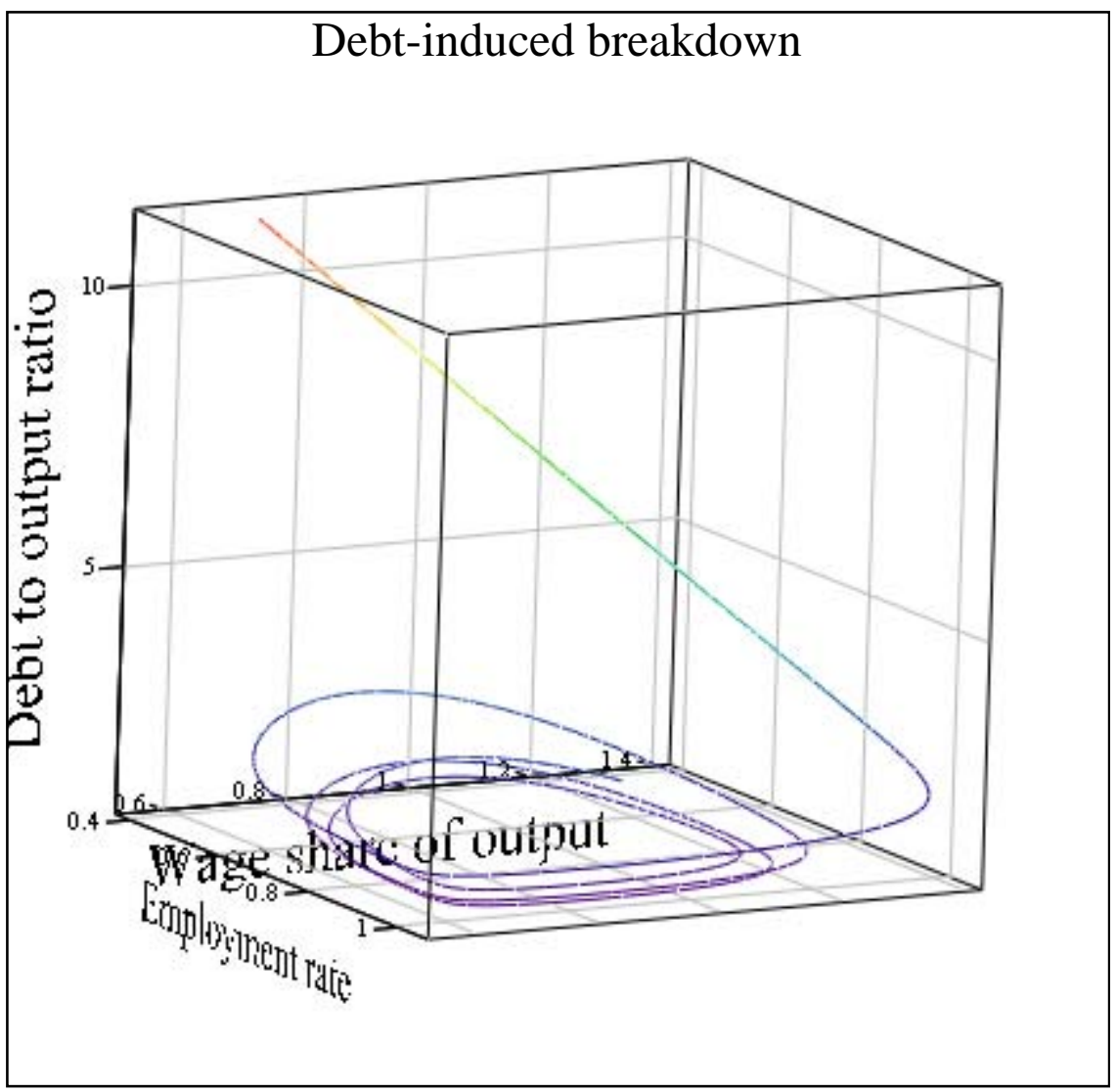

$(\Lambda, \Omega, \Delta)$

\section{Endogenous money}

Though debt was modeled in the preceding system, money was not explicitly considered, and therefore price dynamics were absent. To consider these, the model had to be extended to include an explicit monetary sector. The first step here was to develop a model of an established empirical datum, that credit money is created independently of base money.

The pioneering work on this was done by Basil Moore (1979, 1983, 1988). Contrary to the standard 'money multiplier' model of credit money creation, where base money is created before credit money, Moore concluded (citing Alan Holmes 1969), that:

"In the real world banks extend credit, creating deposits in the process, and look for the reserves later" (Alan Holmes, 1969, p. 73). 
Kydland and Prescott concurred, noting that:

There is no evidence that either the monetary base or $\mathrm{M}_{1}$ leads the cycle, although some economists still believe this monetary myth... if anything, the monetary base lags the cycle slightly... The difference of $M_{2}-M_{1}$ leads the cycle by even more than $M_{2}$, with the lead being about three quarters. (Finn E. Kydland and Edward C. Prescott, 1990, p. 12)

They further concluded that:

The fact that the transaction component of real cash balances $\left(\mathrm{M}_{1}\right)$ moves contemporaneously with the cycle while the much larger nontransaction component $\left(\mathrm{M}_{2}\right)$ leads the cycle suggests that credit arrangements could play a significant role in future business cycle theory. Introducing money and credit into growth theory in a way that accounts for the cyclical behavior of monetary as well as real aggregates is an important open problem in economics. (Finn E. Kydland and Edward C. Prescott, 1990, p. 15)

This open problem was addressed by Graziani (Augusto Graziani, 2003, 1989, 1990, 1995) in a manner that clarified the emphasis that Keynes put on the importance of money, ${ }^{5}$ and explained the well-known difficulties that have been encountered in introducing money into neoclassical models (Arnab Bhattacharjee and Christoph Thoenissen, 2007, Pedro J. Gutierrez, 2004, M.

5 “... as soon as we pass to the problem of what determines output and employment as a whole, we require the complete theory of a monetary economy... For the importance of money essentially flows from its being a link between the present and the future... It is when we have made this transition [to] ... the real world in which our previous expectations are liable to disappointment and expectations concerning the future affect what we do to-day ... that the peculiar properties of money as a link between the present and the future must enter into our calculations... Money in its significant attributes is, above all, a subtle device for linking the present to the future; and we cannot even begin to discuss the effect of changing expectations on current activities except in monetary terms.” (J. M. Keynes, 1936, pp. 293-294) 
Magill and M. Quinzii, 1992, Randall Wright, 2010). Graziani’s simple but profound principle was that "A true monetary economy must ... be using a token money" rather than a commodity as money, since “an economy using as money a commodity coming out of a regular process of production, cannot be distinguished from a barter economy” (Augusto Graziani, 1989, p. 3). From this he derived the proposition that banks, as the creators of these tokens, must be modeled as separate agents from firms and households, and that all transactions are single-commodity, monetary exchanges involving three agents:

any monetary payment must therefore be a triangular transaction, involving at least three agents, the payer, the payee, and the bank. (Augusto Graziani, 1989, p. 3)

A model of a monetary production economy thus must (a) have at the minimum three agents; (b) model demand as the flows of a pure monetary token (which motivate counter-flows of commodities and labor) between bank accounts held by those agents, and (c) allow for the endogenous creation of money by the banking sector.

Steve Keen has developed dynamic disequilibrium models of monetary production that fulfil these conditions (Steve Keen, 2009a, b, 2008, 2010), using a technique that combines doubleentry book-keeping with systems dynamics. Each column of a “Godley Table” (named in honor of Wynne Godley; see Wynne Godley, 1999, Wynne Godley and Marc Lavoie, 2007) is a bank account belonging to a specific class of agent (banker, firm, household), and each row represents financial transactions between these agents that either purchase a good or service, or compound, meet or record a financial obligation. The symbolic sum of the operations in each column then generates the differential equation for that account. In the next section, a simple model of a pure credit economy is combined with the preceding Minsky-Goodwin model to generate a monetary model of the Great Moderation and the Great Recession. 


\section{Modeling Minsky III: Endogenous Money}

There are 5 accounts in the basic model: ${ }^{6}$

1. A Bank Vault $\left(B_{V}\right)$ representing the banking sector's monetary assets;

2. A Bank Transactions Account $\left(B_{T}\right)$ through which all expenditure and interest payments pass; ${ }^{7}$

3. A Firm Loan ledger $\left(F_{L}\right)$-which is not an account that can store money, but a record of the amount of outstanding debt owed by the firm sector to the banking sector; ${ }^{8}$

4. A Firm Deposit Account $\left(F_{D}\right)$ into which money borrowed by the firm sector is deposited; and

5. A Household Deposit Account $\left(H_{D}\right)$ into which wages are paid.

The operations specified in the rows below involve three types of operations: money transfers, accounting operations, and money creation. There are seven money transfers:

1. Lending of money from the bank vault to the firms' deposit accounts (row 1)

2. Payment of interest by firms to the bank's transactions account (row 4)

3. Payment of interest by the bank to firms' deposit accounts (row 6)

4. Payment of wages (row 7)

5. Payment of interest on workers' account balances (row 8)

6. Payment for consumption of the output of firms by bank and workers (row 9)

7. Repayment of loans by firms (row 10)

\footnotetext{
${ }^{6}$ This is a simple stylized model that captures the essence of a monetary economy, and does not purport to reproduce the actual institutional structure of either a single modern bank or the modern banking sector. However the framework can ultimately be extended to these objectives, because the fundamental concepts of both the system and this modeling technique are the same: double-entry book-keeping.

${ }^{7}$ These accounts are kept separate to avoid seignorage, which would occur if banks used their monetary reserves for direct expenditure (Augusto Graziani, 1989, p. 3).

${ }^{8}$ Loans to households are not modeled in this basic system, but can easily be added.
} 
Five steps are ledger entries only, involving the recording of a money transfer related to the level of debt:

8. Recording the loans of the existing money stock to firms (row 2)

9. Compounding the debt at the rate of interest on loans (row 3)

10. Recording the payment of interest on loans (row 5)

11. Recording the repayment of loans (row 11)

12. Recording the endogenous creation of new money (row 13)

One is the crucial step of endogenous money creation in response to the investment desires of firms (in this simple model, all capital expansion is shown as funded by borrowing money from the banking sector):

13. The endogenous creation of new money in response to firms' investment plans (row 12).

Table 1: Basic Godley Table of monetary flows in a growing economy

\begin{tabular}{|l|l|l|l|l|l|l|l|}
\hline Row & Transaction & Type & $\begin{array}{l}\text { Bank } \\
\text { vault } \\
\left(B_{V}\right)\end{array}$ & $\begin{array}{l}\text { Bank } \\
\text { trans- } \\
\text { action } \\
\left(B_{T}\right)\end{array}$ & $\begin{array}{l}\text { Firm } \\
\text { loan } \\
\left(F_{L}\right)\end{array}$ & $\begin{array}{l}\text { Firm } \\
\text { deposit } \\
\left(F_{D}\right)\end{array}$ & $\begin{array}{l}\text { House- } \\
\text { hold } \\
\text { deposit } \\
\left(H_{D}\right)\end{array}$ \\
\hline 1 & Lend money & Money transfer & $-\mathrm{a}$ & & & $\mathrm{a}$ & \\
\hline 2 & Record loan & Ledger entry & & & $\mathrm{a}$ & & \\
\hline 3 & Compound debt & Ledger entry & & & $\mathrm{b}$ & & \\
\hline 4 & Pay interest & Money transfer & & $\mathrm{c}$ & & $-\mathrm{c}$ & \\
\hline 5 & Record payment & Ledger entry & & & $-\mathrm{c}$ & & \\
\hline 6 & Deposit interest & Money transfer & & $-\mathrm{d}$ & & $\mathrm{d}$ & \\
\hline 7 & Wages & Money transfer & & & & $-\mathrm{e}$ & $\mathrm{e}$ \\
\hline 8 & Deposit interest & Money transfer & & $-\mathrm{f}$ & & & $\mathrm{f}$ \\
\hline
\end{tabular}


Monetary Minsky Model of the Great Moderation and Great Recession

\begin{tabular}{|c|c|c|c|c|c|c|c|}
\hline 9 & Consumption & Money transfer & & $-g$ & & $g+h$ & $-\mathrm{h}$ \\
\hline 10 & Repay loan & Money transfer & $\mathrm{i}$ & & & $-\mathrm{i}$ & \\
\hline 11 & $\begin{array}{l}\text { Record } \\
\text { repayment }\end{array}$ & Ledger entry & & & $-\mathrm{i}$ & & \\
\hline 12 & $\begin{array}{l}\text { Investment } \\
\text { finance }\end{array}$ & Money creation & & & & $\mathrm{j}$ & \\
\hline 13 & Record loan & Ledger entry & & & $\mathrm{j}$ & & \\
\hline & Sum of flows & & $\mathrm{i}-\mathrm{a}$ & $\begin{array}{c}c-d-f- \\
g\end{array}$ & $\begin{array}{l}a+b- \\
c-i+j\end{array}$ & $\begin{array}{c}a-c+d- \\
e+g+h- \\
i+j\end{array}$ & $e+f-h$ \\
\hline
\end{tabular}

The fundamental dynamic equations of the financial sector are the sums of the entries in this table, as shown in Equation (1.6):

$$
\begin{aligned}
& \frac{d}{d t} B_{V}(t)=\mathrm{i}-a \\
& \frac{d}{d t} B_{T}(t)=\mathrm{c}-\mathrm{d}-\mathrm{f}-\mathrm{g} \\
& \frac{d}{d t} F_{L}(t)=\mathrm{a}+\mathrm{b}-\mathrm{c}-\mathrm{i} \\
& \frac{d}{d t} F_{D}(t)=\mathrm{a}-\mathrm{c}+\mathrm{d}-\mathrm{e}+\mathrm{g}+\mathrm{h}-\mathrm{i} \\
& \frac{d}{d t} H_{D}(t)=\mathrm{e}+\mathrm{f}-\mathrm{h}
\end{aligned}
$$

Steve Keen (2010) used constant parameters to demonstrate the innate viability of a monetary production economy - something that was disputed in the literature up to that point (Riccardo Bellofiore et al., 2000, Louis-Philippe Rochon, 2005). To generate a monetary Minsky model, I use nonlinear functions for key monetary relationships: the rate at which existing money is circulated, the rate of loan repayment, and the rate of investment (and hence the rate of growth of the money stock) are all made nonlinear functions of the rate of profit. 
The monetary functions are expressed as time constants ${ }^{9}$ whose value at any given time depends upon the rate of profit. The investment function returns the proportion of nominal output devoted to producing investment goods.

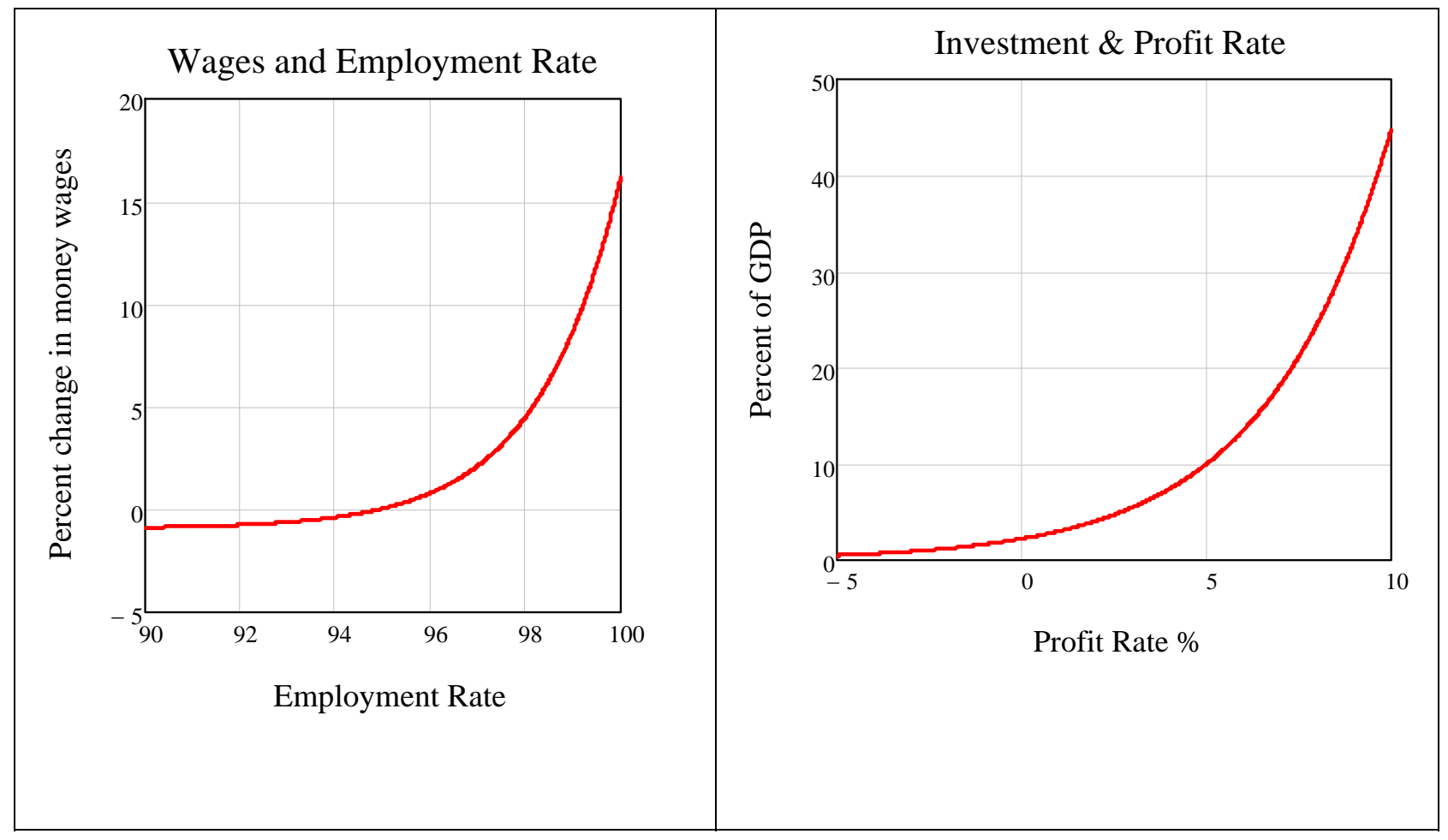

\footnotetext{
${ }^{9}$ The time constants are expressed in years, and provide an intuitive way of describing the speed at which a process occurs. See http://en.wikipedia.org/wiki/Time_constant for a more thorough explanation.
} 
Monetary Minsky Model of the Great Moderation and Great Recession

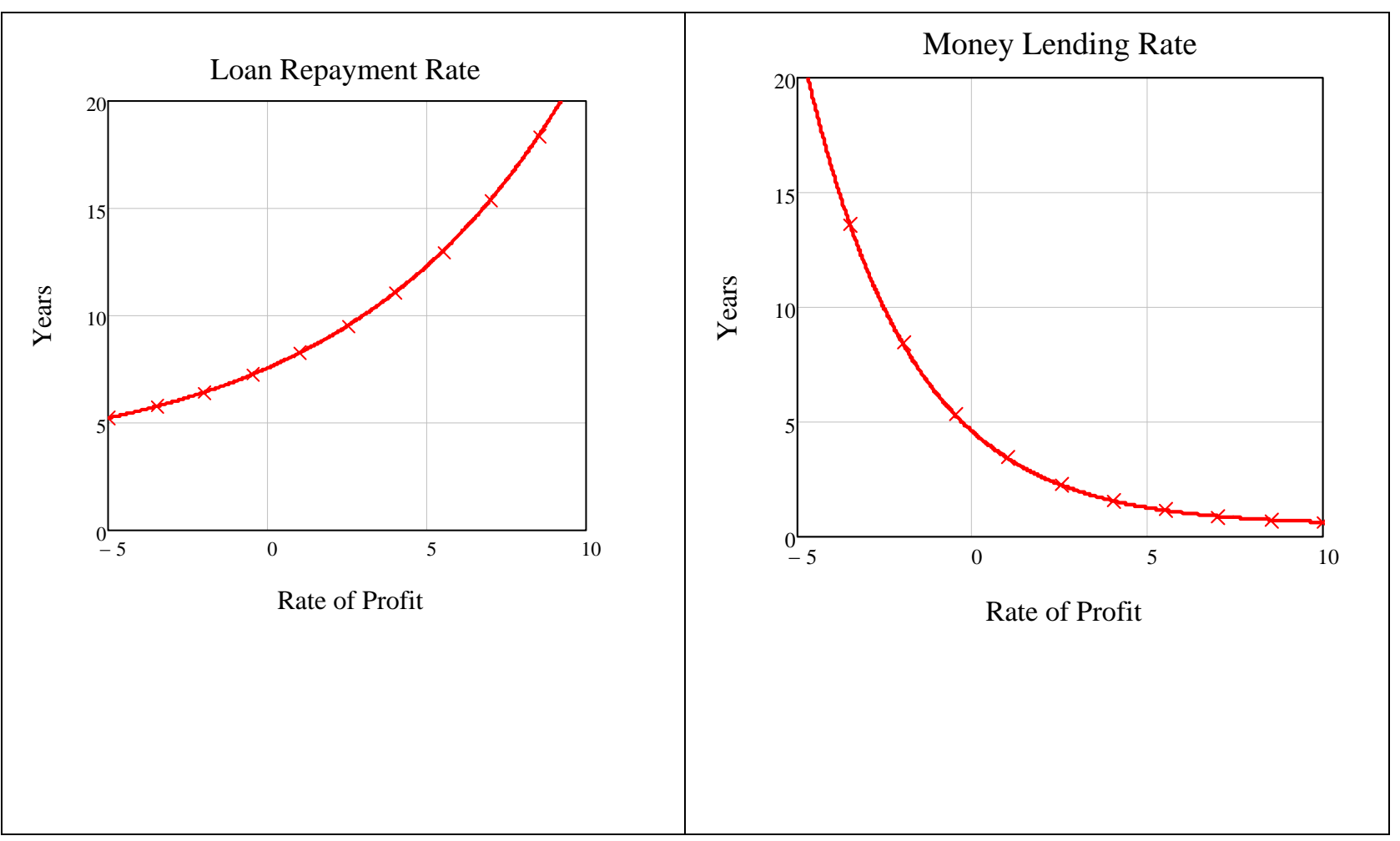

With the definitions provided in Table 2, the financial dynamics of the system are given by Equation (1.7).

Table 2: Flow rates for the entries in the Godley Table

\begin{tabular}{|l|l|l|}
\hline Operation & Description & Equation \\
\hline a & $\begin{array}{l}\text { Lending of the existing money stock not in circulation } B_{V} \\
\text { is a function of the rate of profit }\end{array}$ & $\frac{B_{V}(t)}{\tau_{V}\left(\pi_{r}(t)\right)}$ \\
\hline $\mathrm{b}$ & The debt FL is compounded at the rate of loan interest $r_{L}$ & $r_{L} \cdot F_{L}(t)$ \\
\hline c & Payment of interest on the loan & $r_{L} \cdot F_{L}(t)$ \\
\hline $\mathrm{d}$ & Interest on Firm deposits $F_{D}$ is paid at the deposit rate $r_{D}$ & $r_{D} \cdot F_{D}(t)$ \\
\hline
\end{tabular}


Monetary Minsky Model of the Great Moderation and Great Recession

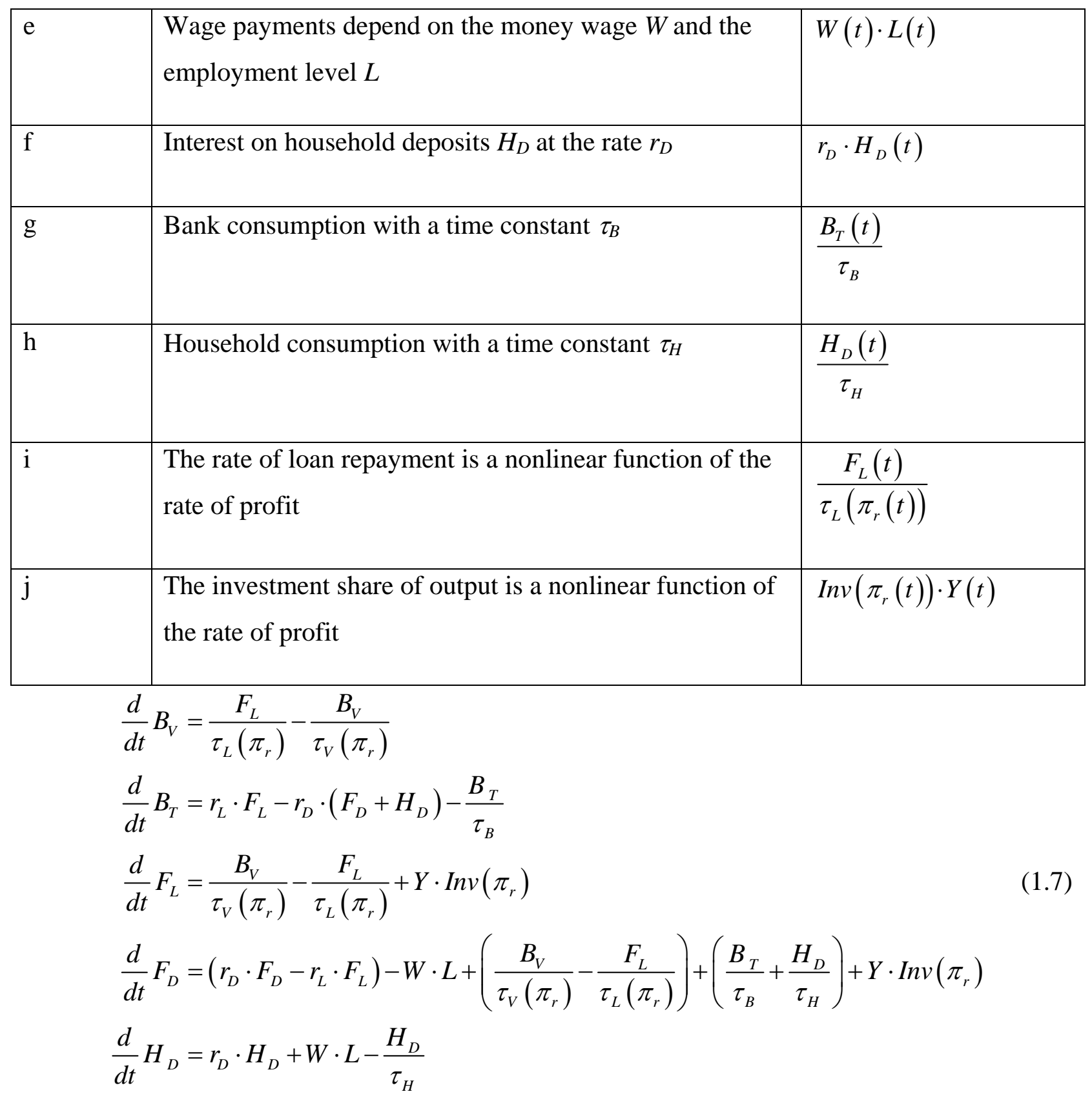

This financial system is coupled to the physical production model via prices. Physical measures of capital and output are now specified as being in real terms:

$$
\begin{aligned}
& Y_{R}=\frac{K_{R}}{v} \\
& L=\frac{Y_{R}}{a}
\end{aligned}
$$


The dynamic disequilibrium price equation is consistent with empirical research into actual price setting behavior (Alan S. Blinder, 1998, Frederic S. Lee, 1998) and is derived analytically in (Steve Keen, 2010) from the equilibrium condition for physical output and the physical demand for commodities. Prices converge to a markup over the monetary cost of production, where the markup factor $(1-\sigma)$ is equivalent to the equilibrium workers' share of real output:

$$
\frac{d}{d t} P=-\frac{1}{\tau_{P}} \cdot\left(P-\frac{1}{1-\sigma} \frac{W}{a}\right)
$$

The money wage setting relation is fully consistent with Phillips's original paper, in which he specified not one but three factors that determine the rate of change of money wages: the relationship between the rate of change of money wages and level of unemployment, which is "highly non-linear"; the "rate of change of the demand for labour, and so of unemployment"; and "the rate of change of retail prices, operating through cost of living adjustments in wage rates" (A. W. Phillips, 1958, p. 283). The full wage-setting equation is thus:

$$
\frac{d}{d t} W=W \cdot\left(P_{h}(\lambda)+\omega \cdot \frac{1}{\lambda} \frac{d}{d t} \lambda+\frac{1}{P} \frac{d}{d t} P\right)
$$

where $\omega<1$ is a weighting factor for the impact of the change in the employment rate on the wage rate.

The rate of inflation is given by Equation (1.9) above. The rate of change of the employment rate $\lambda$ is:

$$
\frac{d}{d t} \lambda=\lambda \cdot(g-(\alpha+\beta))
$$

where as before, $\alpha$ is the rate of technical change, $\beta$ the rate of population growth, and $\delta$ the depreciation rate. $g$ is the real growth rate, which is determined by the rate of investment and depreciation, which in turn determine the rate of growth of the real capital stock $K_{r}$ :

$$
\begin{aligned}
& g=\frac{\operatorname{Inv}\left(\pi_{r}\right)}{v}-\delta \\
& \frac{d}{d t} K_{R}=g \cdot K_{R}
\end{aligned}
$$


The profit rate is now defined in fully monetary terms:

$$
\pi_{r}=\frac{P \cdot Y_{R}-W \cdot L-\left(r_{L} \cdot F_{L}-r_{D} \cdot F_{D}\right)}{P \cdot K_{R}}
$$

Together with the technical change and population growth equations specified in Equation (1.5), these equations provide a strictly monetary model of Minsky’s Financial Instability Hypothesis. The qualitative behavior of this model reproduces the features of the last 30 years: a period of strong cycles in real output is followed by a period when the business cycle appears a thing of the past, but then suddenly a crisis breaks out with declining real output.

Figure 8: Cycles in real output diminish, followed by a sudden change to declining output

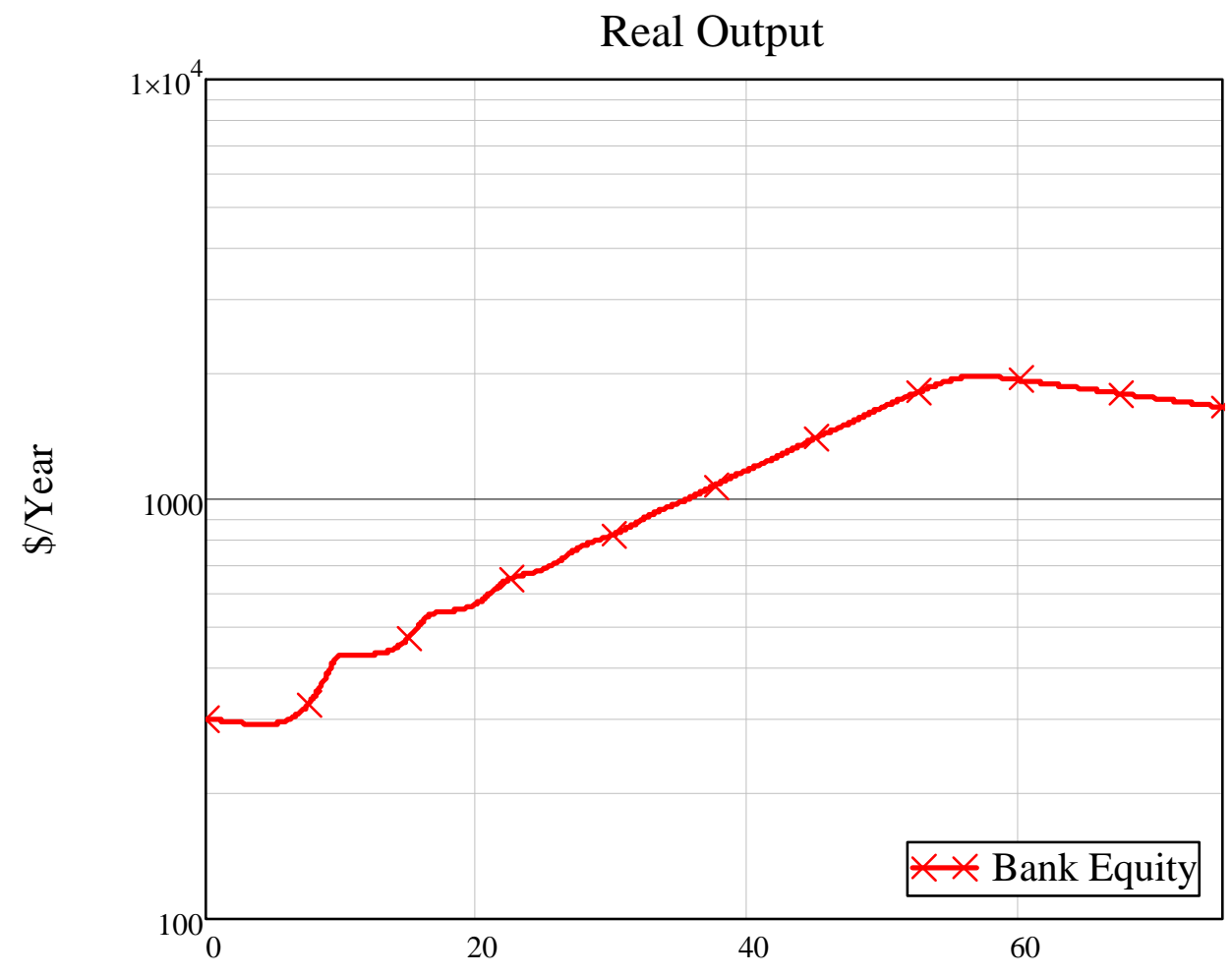

Similarly, declining cycles in unemployment and inflation appear to imply that the system is becoming more stable, when suddenly inflation gives way to deflation and unemployment grows dramatically (see Figure 9). 
Figure 9: Apparent economic tranquility gives way to a deflationary collapse

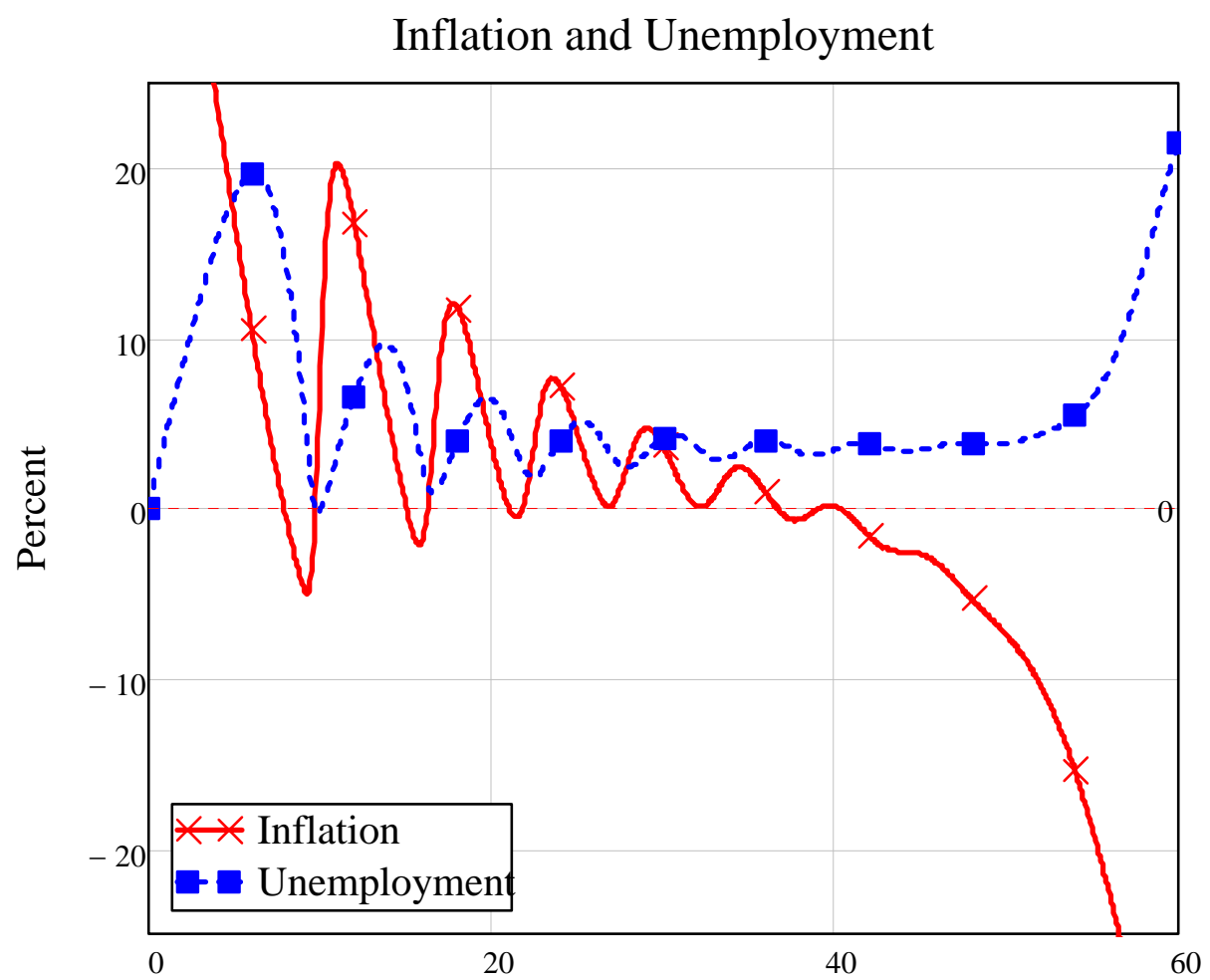

The cause of this breakdown is the level of debt (which has been growing cyclically in the manner predicted by Minsky), which reaches a level where it is no longer possible for the debt to be serviced by capitalists. Absent bankruptcy provisions (which are not yet modeled) the debt ratio grows exponentially, leading to a terminal economic breakdown-a Great Depression. 
Figure 10: Cyclical growth in the debt to output ratio, followed by exponential growth

Debt to Output Ratio

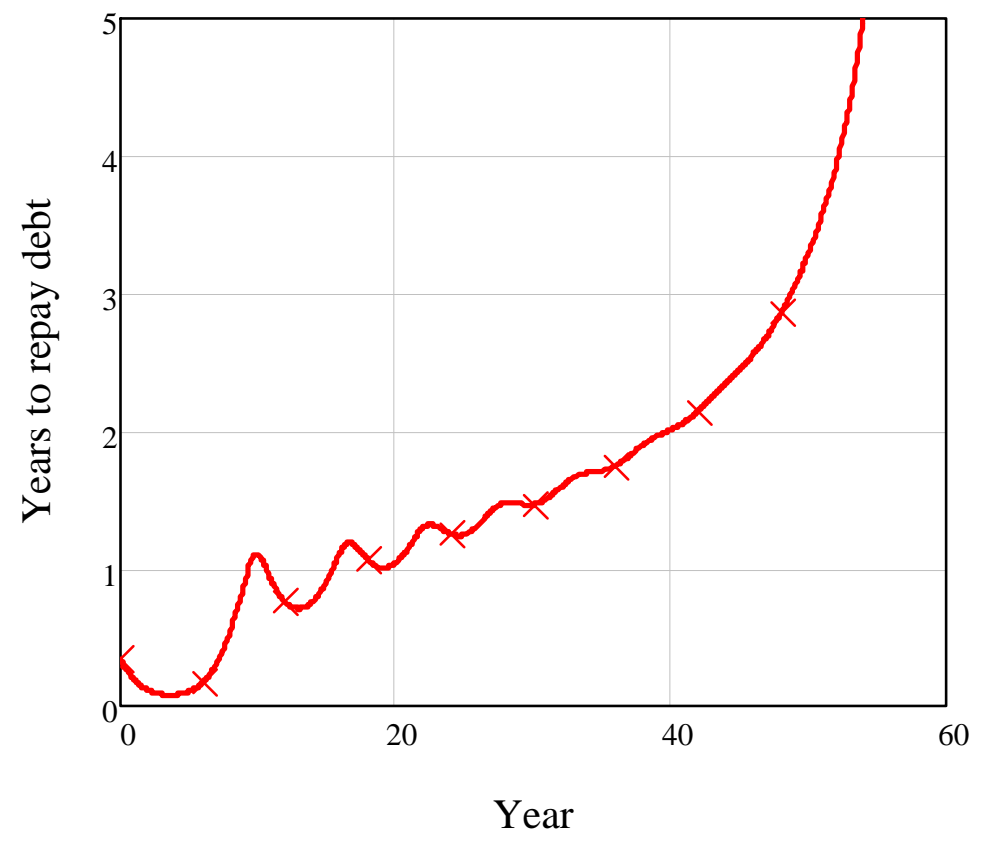

The income distribution dynamics of the model also match the empirical record, and maintains the analytic result shown in Steve Keen (2000, p. 93) that, though capitalists are the ones who incur debt in this model, the dynamics of the system transfer this cost to workers. The wages share of output declines as debt levels rise, while the profit rate cycles around its equilibrium value before the final collapse (when exponential growth in the debt ratio means that bankers' share of income explodes as income collapses). 


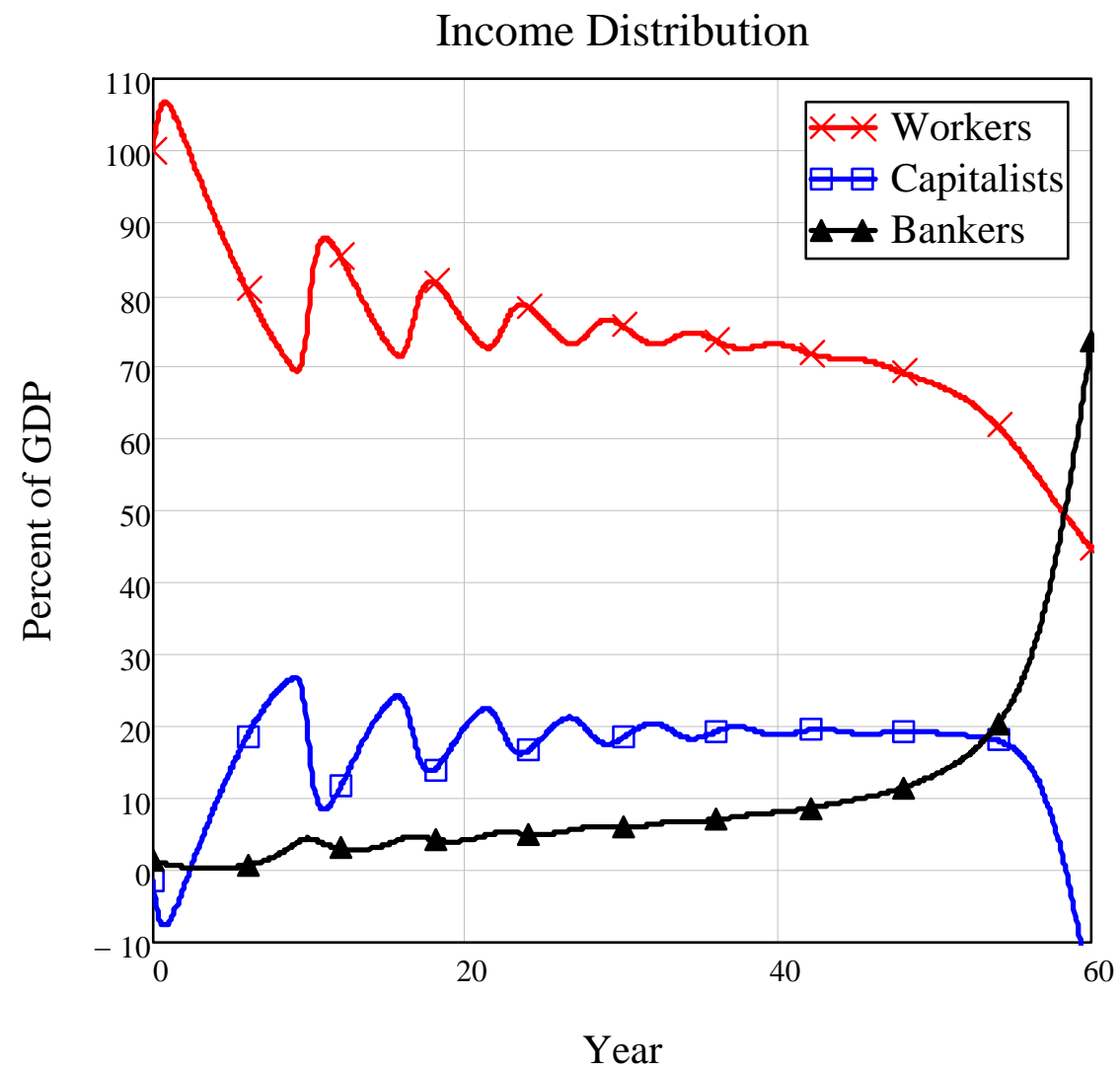

As a strictly monetary system, the model also captures another real-world phenomenon that has perplexed standard economic analysis: the reduction in business debt and the dramatic growth in bank reserves during the economic collapse. 
Figure 11: Loans and deposits fall and unlent reserves rise as the crisis unfolds

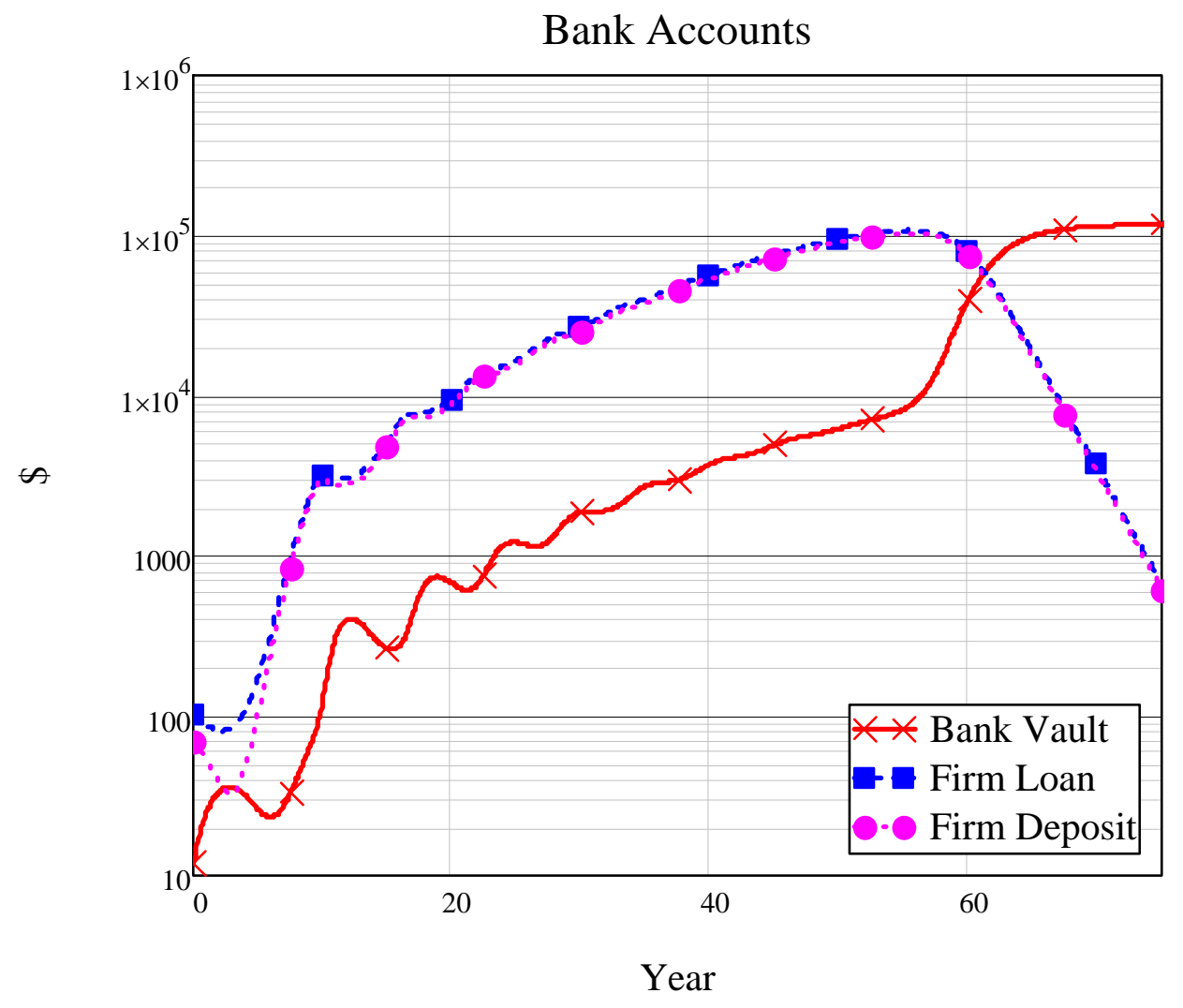

\section{Conclusion}

The results of this model are more extreme than our actual economic situation, partly because aspects of Minsky's hypothesis have been omitted for simplicity (such as the proposition that the price level for capital goods is set in a different manner to that for ordinary commodities; Hyman P. Minsky, 1982, p. 79), partly because aspects of reality have been omitted for the same reason (such as interest rates varying with the rate of inflation), and partly because the impact of government spending has not been considered (it is considered in the simpler non-monetary model in Steve Keen, 2000, pp.100-105).

However, though much could be done to enhance its realism, in its present form it provides an explanation not only of the Great Recession, but also the Great Moderation that preceded it. The fact that this model is relevant to today’s economic predicament vindicates Minsky’s stricture from 1982 that, if we are to fully comprehend how market economies really behave, "it is 
Monetary Minsky Model of the Great Moderation and Great Recession

necessary to have an economic theory which makes great depressions one of the possible states in which our type of capitalist economy can find itself.” (Hyman P. Minsky, 1982a, p. 5)

\section{Appendix}

\begin{tabular}{|c|c|c|}
\hline Variable or Parameter & Description & Value \\
\hline $\mathrm{V}$ & Accelerator relation & 3 \\
\hline$\alpha$ & $\begin{array}{l}\text { Rate of change of labor } \\
\text { productivity }\end{array}$ & 2\% p.a. \\
\hline$\beta$ & Rate of population growth & 1\% p.a. \\
\hline$\gamma$ & Depreciation rate & 1\% p.a. \\
\hline$P_{h}(\lambda)=-c+d \cdot \lambda$ & $\begin{array}{l}\text { Linear Phillips curve for } \\
\text { Goodwin model }\end{array}$ & $c=4.8, d=5$ \\
\hline$L_{0}, w_{0}, a_{0}, N_{0}$ & $\begin{array}{l}\text { Initial conditions for Labor, } \\
\text { real wage, labor } \\
\text { productivity and population } \\
\text { in the Goodwin model }\end{array}$ & 300,0.95,1,300 resp. \\
\hline$D_{0}$ & $\begin{array}{l}\text { Initial condition for debt in } \\
\text { the Minsky model }\end{array}$ & 0 \\
\hline$P_{h}(\lambda)=\operatorname{GenExp}(\lambda, 0.95,0,0.5,-0.01)$ & $\begin{array}{l}\text { Parameters for nonlinear } \\
\text { Phillips curve in the Minsky } \\
\text { model }\end{array}$ & \\
\hline$I\left(\pi_{r}\right)=\operatorname{GenExp}\left(\pi_{r}, 0.05,0.05,1.75,0\right)$ & $\begin{array}{l}\text { Parameters for nonlinear } \\
\text { investment function in the } \\
\text { Minsky model }\end{array}$ & \\
\hline$B_{V 0}, B_{T 0}, F_{L 0}, F_{D 0}, H_{D 0}$ & $\begin{array}{l}\text { Initial conditions for } \\
\text { financial variables in the } \\
\text { monetary Minsky model }\end{array}$ & $12,5,100,70,13$ \\
\hline$L_{0}, W_{0}, a_{0}, N_{0}, K_{R 0}, Y_{R 0}, P_{0}$ & $\begin{array}{l}\text { Initial conditions for } \\
\text { physical variables in the } \\
\text { monetary Minsky model }\end{array}$ & $300,300,1,300,900,300,1$ \\
\hline
\end{tabular}


Monetary Minsky Model of the Great Moderation and Great Recession

\begin{tabular}{|l|l|l|}
\hline$r_{L}, r_{D}, \sigma, \tau_{B}, \tau_{H}, \tau_{P}$ & $\begin{array}{l}\text { Loan and deposit interest } \\
\text { rates, markup coefficient, } \\
\text { time constants for bank and } \\
\text { household consumption and } \\
\text { price setting }\end{array}$ & \\
\hline$\omega$ & $\begin{array}{l}\text { Weighting factor on impact } \\
\text { of change in the } \\
\text { employment rate on wage }\end{array}$ & $10 \%$ \\
& setting & \\
\hline
\end{tabular}

\section{Bibliography}

Bellofiore, Riccardo; Guglielmo Forges Davanzati and Riccardo Realfonzo. 2000. "Marx inside the Circuit: Discipline Device, Wage Bargaining and Unemployment in a Sequential Monetary Economy." Review of Political Economy, 12(4), 403-17.

Bellofiore, R. and Piero Ferri. 2001. The Economic Legacy of Hyman Minsky. Cheltenham, U.K. ; Northampton, Mass., USA: Edward Elgar Publishers.

Benati, Luca and Paolo Surico. 2009. "Var Analysis and the Great Moderation." American Economic Review, 99(4), 1636-52.

Bernanke, Ben S. 2004. "The Great Moderation: Remarks by Governor Ben S. Bernanke at the Meetings of the Eastern Economic Association, Washington, Dc February 20, 2004," Eastern Economic Association. Washington, DC: Federal Reserve Board,

Bezemer, Dirk J. 2009. "“No One Saw This Coming”: Understanding Financial Crisis through Accounting Models," Groningen, The Netherlands: Faculty of Economics University of Groningen, . 2010. "Understanding Financial Crisis through Accounting Models." Accounting, Organizations and Society, 35(7), 676-88.

Bhattacharjee, Arnab and Christoph Thoenissen. 2007. "Money and Monetary Policy in Dynamic Stochastic General Equilibrium Models." Manchester School, 75, 88-122.

Blinder, Alan S. 1998. Asking About Prices : A New Approach to Understanding Price Stickiness. New York: Russell Sage Foundation. 
Davis, Steven J and James A Kahn. 2008. "Interpreting the Great Moderation: Changes in the Volatility of Economic Activity at the Macro and Micro Levels." Journal of Economic Perspectives, 22(4), 155-80.

Friedman, Milton. 1953. "The Methodology of Positive Economics," Essays in Positive Economics. Chicago: University of Chicago Press,

Fullbrook, Edward. 2010. "Keen, Roubini and Baker Win Revere Award for Economics," E. Fullbrook, Real World Economics Review Blog. New York: Real World Economics Review, Galbraith, James K. 1955. The Great Crash 1929. Boston.: Houghton Mifflin Company. Gali, Jordi and Luca Gambetti. 2009. "On the Sources of the Great Moderation." American Economic Journal: Macroeconomics, 1(1), 26-57.

Godley, Wynne. 1999. "Money and Credit in a Keynesian Model of Income Determination." Cambridge Journal of Economics, 23(4), 393-411.

Godley, Wynne and Marc Lavoie. 2007. Monetary Economics: An Integrated Approach to Credit, Money, Income, Production and Wealth. New York: Palgrave Macmillan.

Goodwin, Richard. 1967. "A Growth Cycle," C. H. Feinstein, Socialism, Capitalism and Economic Growth. Cambridge: Cambridge University Press, 54-58.

Graziani, Augusto. 2003. The Monetary Theory of Production. Cambridge, UK: Cambridge University Press. . 1989. "The Theory of the Monetary Circuit." Thames Papers in Political Economy, Spring, 1-26. . 1990. "The Theory of the Monetary Circuit." Economies et Societes, 24(6), 7-36. . 1995. "The Theory of the Monetary Circuit," M. Musella and C. Panico, The Money Supply in the Economic Process: A Post Keynesian Perspective. Aldershot, U.K: Elgar Reference Collection. International Library of Critical Writings in Economics, 516-41. Gutierrez, Pedro J. 2004. "Money, Prices and Interest Rates in a Non-Aggregate Stochastic General Equilibrium Model." Applied Mathematical Finance, 11(4), 283-316.

Holmes, Alan R. 1969. "Operational Contraints on the Stabilization of Money Supply Growth," F. E. Morris, Controlling Monetary Aggregates. Nantucket Island: The Federal Reserve Bank of Boston, 65-77.

Keen, Steve. 1995. "Finance and Economic Breakdown: Modeling Minsky's 'Financial Instability Hypothesis.'." Journal of Post Keynesian Economics, 17(4), 607-35. 
. 2000. "The Nonlinear Economics of Debt Deflation," W. A. Barnett, Commerce, Complexity, and Evolution: Topics in Economics, Finance, Marketing, and Management: Proceedings of the Twelfth International Symposium in Economic Theory and Econometrics. New York: Cambridge University Press, 83-110. . 2001. "Minsky's Thesis: Keynesian or Marxian?," R. Bellofiore and P. Ferri, The Economic Legacy of Hyman Minsky. Volume 1. Financial Keynesianism and Market Instability. Cheltenham, U.K.: Edward Elgar, 106-20. . 2007. "Deeper in Debt: Australia's Addiction to Borrowed Money," Occasional Papers. Centre for Policy Development . 2008. "Keynes’s 'Revolving Fund of Finance’ and Transactions in the Circuit," R. Wray and M. Forstater, Keynes and Macroeconomics after 70 Years. Cheltenham: Edward Elgar, 25978.

. 2009a. "Bailing out the Titanic with a Thimble." Economic Analysis \& Policy, 39(1), 3-24. . 2009b. "The Dynamics of the Monetary Circuit," S. Rossi and J.-F. Ponsot, The Political Economy of Monetary Circuits: Tradition and Change. London: Palgrave Macmillan, 161-87. . 2010. "Solving the Paradox of Monetary Profits." Economics: The Open-Access, Open Assessment E-Journal, 4(2010-31).

Keynes, J. M. 1937. "The General Theory of Employment." The Quarterly Journal of Economics, 51(2), 209-23. . 1936. The General Theory of Employment, Interest and Money. London: Macmillan.

Kydland, Finn E. and Edward C. Prescott. 1990. "Business Cycles: Real Facts and a Monetary Myth." Federal Reserve Bank of Minneapolis Quarterly Review, 14(2), 3-18.

Lee, Frederic S. 1998. Post Keynesian Price Theory. Cambridge: Cambridge University Press. Magill, M. and M. Quinzii. 1992. "Real Effects of Money in General Equilibrium." Journal of Mathematical Economics, 21(4), 301-42.

Minsky, Hyman. 1957. "Monetary Systems and Accelerator Models." American Economic Review, 67, 859-83. . 1971. "The Allocation of Social Risk: Discussion." American Economic Review, 61(2), 389-90. . 1975. John Maynard Keynes. New York: Columbia University Press. . 1982a. "Can 'It' Happen Again? A Reprise." Challenge, 25(3), 5-13. 

. 1982b. Can "It" Happen Again? : Essays on Instability and Finance. Armonk, N.Y.: M.E. Sharpe. . 1986. Stabilizing an Unstable Economy. Twentieth Century Fund Report series, New Haven and London: Yale University Press.

Moore, Basil J. 1979. "The Endogenous Money Stock." Journal of Post Keynesian Economics, 2(1), 49-70.

_ 1983. "Unpacking the Post Keynesian Black Box: Bank Lending and the Money Supply." Journal of Post Keynesian Economics, 5(4), 537-56.

• 1988. "The Endogenous Money Supply." Journal of Post Keynesian Economics, 10(3), 372-85.

Phillips, A. W. 1958. "The Relation between Unemployment and the Rate of Change of Money Wage Rates in the United Kingdom, 1861-1957." Economica, 25(100), 283-99.

Pomeau, Yves and Paul Manneville. 1980. "Intermittent Transition to Turbulence in Dissipative Dynamical Systems." Communications in Mathematical Physics, 74, 189-97.

Rochon, Louis-Philippe. 2005. "The Existence of Monetary Profits within the Monetary

Circuit," G. Fontana and R. Realfonzo, Monetary Theory of Production: Tradition and Perspectives. Basingstoke: Palgrave Macmillan, 125-38.

Wright, Randall. 2010. "A Uniqueness Proof for Monetary Steady State." Journal of Economic Theory, 145(1), 382-91.

u 